\title{
A concept of operational lawmaking technology
}

\author{
Kadriddin Minhodzhidinovich Umedov ${ }^{1,2, *}$ \\ ${ }^{1}$ Russian-Tajik (Slavonic) University (RTSU), M. Tursun-zade st., 30, 734025 Dushanbe, Tajikistan \\ ${ }^{2}$ Peoples' Friendship University of Russia (RUDN), Miklukho-Maklaya st., 6, 117198 Moscow, \\ Russia
}

\begin{abstract}
The technology of operational lawmaking is a subtype of lawmaking technology; the latter is a type of legal technology. The technology of operational lawmaking is characterized by an emergency, extraordinary content; suddenly emerging social relations are the main characteristic of this phenomenon, the core and basis of operational lawmaking. There is no doubt that there is a peculiar nature of operational lawmaking (phenomenon). "Challenge accepted" - a heading of T. Zamakhina's article: The State Duma and the Federation Council promptly adopted a package of laws aimed at implementing the initiatives of the President of the Russian Federation to support citizens and the state's economy in connection with the spread of COVID-19 [1]. The subject of this study is the technology of operational lawmaking. The objective of this study is to prove that there is a separate, independent "operational lawmaking technology" along with the current (usual) technology of lawmaking. The study used the following methods: dialectical, logical, systemic, comparative, structural-functional, and statistical. The following results were achieved: it was revealed that the "operational lawmaking technology" exists as an independent phenomenon with its own specific features, has its own content and form, and, accordingly, the concept is produced in crisis situations, presupposes a special strategy, tactics, approaches and methods.
\end{abstract}

\section{Introduction}

Lawmaking is generally a quite complex, multifaceted, multi-level, and multifunctional process, responsible activity, as the product (law) becomes the equalizer of each subject of law, and primarily a person.

Power-making and lawmaking are inextricably linked, as lawmaking is a type of powermaking, a legal activity to form and formalize law into a regulatory legal act (law), which has a special status in the hierarchy of regulatory legal acts. Lawmaking implements the functions and goals of power-making.

"Law" covers two very different decision-making processes: judgment and Law [2, p. 585]. The judgment and the Law must be legal, otherwise, it is not a legal law; such laws must be promptly brought in accordance with the law.

\footnotetext{
* Corresponding author: kadridin1979@mail.ru
} 
The operational lawmaking technology is carried out at a faster pace, the adoption of a law, in connection with the laws of the development of society, or it arises suddenly and is of an "emergency" nature, may be due to the poor-quality created system of law and its institutions, the transition period of states. Conflict norms and gaps make the lawmaking body in the shortest possible time to correct the identified conflicts and fill in the gaps with an appropriate norm. In such situations, efficiency manifests itself clearly enough; any problem must be addressed promptly. Collisions, gaps, uncertainties, and duplication of legal norms are the basis for operational lawmaking; in such cases, the legislative body needs to promptly develop appropriate draft laws, as the above-mentioned "negative" qualities of the legal system do not correspond to the principles of law, principles of powermaking, principles of lawmaking, and are subject to immediate correction.

Operational rule-making is a quick elimination of gaps in legislation, timely cancellation and amendment of outdated acts [3, p. 234].

The need for lawmaking arises when gaps, collisions, duplication appear, or when new social relations arise [4, p.238]. Collisions, gaps, uncertainties, and duplication act as a disease (infection) of law that must be promptly corrected (improved).

The operational lawmaking technology may be caused due to the adoption of international obligations by the state, in accordance with the Resolution of the Constitutional Court.

Acts of the Constitutional Court have a special status and specific technology for their formation. Guk V.A. writes that judicial activity creates a kind of ground for lawmaking and rule-making [5, p. 214.].

Legislative tactics and models become noticeable when considering the relationship between the pace of adoption of legislative rules and the central democratic unit of time, the period of elections to parliament and government [6, p. 7]. The conclusion is scientifically based. The period of formation of the parliament and government directly affects the course of lawmaking, and the reforms carried out in the state and the reformation of the mechanism for the structure of state bodies can affect the pace of the lawmaking process. It should be noted that, in such cases, the process of lawmaking may either accelerate or slow down.

Operational lawmaking begins from an unforeseen emergency situation. New public relations requiring immediate (operational) impact in order to ensure public safety, issues related to the sovereignty of the state and society, protection of human life, protection of the economy, nature and all its components (fauns and flora, fauna, etc.), ecology, etc. can be considered the first stage of the technology of operational lawmaking.

The technology of operational lawmaking is an unstudied and unformed phenomenon; therefore, today it is necessary to systematize the technology of operational lawmaking, to give it form and content for perception and quality application. The quality of the law in operational lawmaking is more difficult to achieve than in current lawmaking, operational lawmaking is a complex activity and an unexplored process.

The technology of operational lawmaking is most susceptible to error, as it is carried out in a hurry. "Haste makes waste" [7, p. 504] is said and presented as advice to act slowly to avoid mistakes and errors. Therefore, today the topic of technology of operational lawmaking is relevant.

Efficiency has its own characteristics; this phenomenon (concept), a special mechanism and an organism is a separate system. The result of lawmaking is a law, therefore, research and identification of specific features, signs, principles, stages, learning to professionally manage an emergency situation that has arisen, and, accordingly, quickly resolve the issues and problems that have arisen, are in demand, which creates a condition for the relevance of the chosen topic. 


\section{Materials and Methods}

The methodological basis of the research included the following methods: analytical, logical, systemic, historical-legal, comparative-legal, formal-legal, and functional. The theoretical basis is formed by the works of the theory of law, the theory of lawmaking and power-making, as well as legal technology and technique. The regulatory framework consists of laws and regulations of Russia and Tajikistan.

\section{Results and Discussion}

Liubiaschits V.Ia. [8, p. 392], Matuzov N.I., and Malko A.V. [9, p. 292-293] present efficiency as a principle of lawmaking, implying the timely publication of regulatory legal acts.

How to understand the timeliness of the publication of regulatory legal acts? It is a period of time, and what moment should be considered the beginning of this time? The result, the end of the legislative process is clear - it is the publication of the law, but what the beginning is? It is a very complex and abstract question.

Of course, the authors are right that every regulatory legal act should be issued in a timely manner. Each process must be implemented within the period that is allotted to it. That is, efficiency, in this case, suggests that the regulatory legal act should be issued in a timely manner, within a reasonable time frame, unless otherwise provided for a specific act. 57].

Operational legislative regulation is carried out by means of "decree" lawmaking [10, $p$.

Decrees of the head of state are subordinate and the process of their creation can be attributed to power-making in the form of issuing subordinate regulatory legal acts of the Head of State. This process refers to operational power-making, rather than lawmaking. Not only the decrees of the head of state but practically all by-laws of the executive branch are of an operational nature; "one of the characteristics of the by-law regulatory legal act (BLRLA) is its urgency" [11, p. 193].

There are cases of extreme necessity when high-speed lawmaking is not just justified but necessary to protect the rights and interests of Russians. The "emergency" draft law must be well elaborated [12].

The number of laws and the speed of their change by no means reflect the quality of the legal environment [13, p. 2]. Shulman E.M. notes correctly, saying that the speed of adoption of the law does not guarantee its quality. "Quality" is the highest value of a regulatory legal act, including the law.

COVID-19 forced the state to independently and individually coordinate and begin to quickly address the problem. Russia quite quickly took a number of measures to identify, study, and eliminate the COVID-19. In lawmaking, this manifested itself in the operational change of many regulatory legal acts. First of all, on January 31, 2020, an amendment was made to the Decree of the Government of the Russian Federation No. 715 of December 1, 2004, "On the approval the list of socially significant diseases and the list of diseases that pose a danger to others" [14]. The list of diseases that pose a danger to others was replenished with a new type of disease - "COVID-19" [15].

The Decree of the Government of the Russian Federation No. 66 was issued on January 31, 2020, and on April 1, 2020, FZN 98-FZ was issued "On amendments to certain legislative acts of the Russian Federation on the prevention and elimination of emergencies". This law, along with other changes, amended the Federal Law No. 68-FZ dated December 21, 1994, "On the protection of the population and territories from natural and man-made emergencies" as follows: "the spread of a disease that poses a danger to 
others" [16]. As a result of the spread of COVID-19 became the basis for declaring a state of emergency.

We shall consider the complementary and combining federal laws of Russia adopted through operational lawmaking in an emergency period:

- $\quad$ Federal Law No. 27-FZ dated 27.02.2020 [17];

- Federal Law No. 98-FZ dated 01.04.2020 [18];

- Federal Law No. 149-FZ dated 24.04.2020 [19];

- Federal Law No. 147-FZ dated 24.04.2020 [20];

- Federal Law No. 124-FZ dated 24.04.2020 [21];

- Federal Law No. 153-FZ dated 23.05.2020 [22];

- Federal Law No. 154-FZ dated 23.05.2020 [23];

- Federal Law No. 166-FZ dated 08.06.2020 [24];

- $\quad$ Federal Law No. 181-FZ dated 08.06.2020 [25];

- Federal Law No. 202-FZ dated 13.07.2020 [26];

- Federal Law No. 267-FZ dated 31.07.2020 [27].

In Russia, in early 2020, lawmaking intensified and took on operational features. A large number of laws have been issued, and a huge array of acts of changes has been formed. It was very difficult to adapt to the emerging emergency and avoid a mistake.

Federal Law "On insolvency (bankruptcy)" [28] was amended as follows: 01.04.2020 N 98-FZ; 24.04.2020 N 149-FZ; 08.06.2020 N 166-FZ; 08.06.2020 N 181-FZ; 13.07.2020 N 202-FZ.

Federal Law "On basic guarantees of electoral rights and the right to participate in a referendum of citizens of the Russian Federation" [29] was amended as follows: 27.02.2020 N 27-FZ; 01.04.2020 N 98-FZ; 23.05.2020 N 153-FZ; 23.05.2020 N 154-FZ; 31.07.2020 N 267-FZ.

Federal Law "On the election of deputies of the State Duma of the Federal Assembly of the Russian Federation" [30] was amended as follows: 27.02.2020 N 27-FZ; 23.05.2020 N 153-FZ; 23.05.2020 N 154-FZ; 31.07.2020 N 267-FZ.

Why is a supplement to one law drawn up by different laws on amendments that were made on the same day - Federal Law dated 08.06.2020 N 166-FZ, and dated 08.06.2020 N 181-FZ or dated 23.05.2020 N 153-FZ, and dated 23.05.2020 N 154-FZ.

Why are the rules of one institution split into different laws adopted on the same day? When can it be done differently? Firstly, this kind of approach is non-systemic, and only complicates lawmaking and clogs the system of law; and secondly, it is not permissible from the point of view of legal (judicial) technology. The system of law must be streamlined; when issuing any normative legal act, the structure of the relevant branch of law must be analyzed and a new rule in the system of law must be placed, as the builder puts a "brick" on the wall of the house under construction.

Federal Law "On contract system in the procurement of goods, works and services for state and municipal needs" [31] was amended as follows: 27.02.2020 N 27-FZ; 01.04.2020 N 98-FZ; 04.04.2020 N 107-FZ; 24.04.2020 N 124-FZ; 08.06.2020 N 180-FZ.

Federal Law "On circulation of medicines" was amended as follows: $26.03 .2020 \mathrm{~N} 67-$ FZ; [32] 01.04.2020 N 98-FZ; 03.04.2020 N 105-FZ; [33] and 13.07.2020 N 206-FZ.

Take a look at the amendments to the Federal Law "On circulation of medicines", on the first and third of April, with a two-day interval.

In addition, the aforementioned supplementing laws themselves were amended. For example, the Federal Law dated 01.04.2020 N 98-FZ was amended with Federal Law dated 27.02.2020 N 27-FZ, further Federal Law dated 01.04.2020 N 98-FZ was amended with Federal Law dated 08.06.2020 N 166-FZ.

Speaking about the quality of the law, Bakhvalov S.V. notes that, firstly, a lot of changes in a short period of the existence of the law suggests that the law does not function 
well now and is designed for the future or the past; and secondly, changes in laws are unevenly distributed over the branches of public life [34, p.48].

There is not a single state that could say it was ready to respond to COVID-19. Each state had the right to make mistakes in the legislative process.

In Soviet times, the expression "Who never climbed never fell" was attributed to Lenin in the canonical article "On the Significance of Militant Materialism" (1922). It was also quoted in Lenin's report at the V Congress of Soviets on July 5, 1918: "Who never climbed never fell" [35].

\section{Conclusions}

The technology of operational lawmaking is a type of multilevel, multifunctional, scientific and creative, public, political and legal, systemic, urgent lawmaking technology, which is produced in emergency situations. It is aimed at eliminating legislative errors, preventing and eliminating socially dangerous consequences that may arise with the emergence of an unforeseen emergency, at fulfilling international obligations and at implementing the Resolution of the Constitutional Court. Guided by the principles of law, the principles of lawmaking, its own principles, which has stages, an object and a subject, has separate subjects and participants, considering the legal ideology and legal culture. Possessing technical and legal tools, which are methods and means (legal technique), forecasting, monitoring, strategy and tactics aimed at creating legal, civilized, highly cultural, high-tech laws, or abolishing legal regulations.

The studied material discovers chaos in the changes in legislation, unplanned, uncontrolled subject diversity, illegibility; it is impossible to see the strategy, tactics and methods used in operational lawmaking. To put it mildly, forecasting, strategy, tactics, plans, methods and means of legal technology were not considered.

Emphasis must be placed on approaches, principles, rules, methods, techniques, and means. It is necessary to use the entire range of law and legal (judicial) technology. Otherwise, the laws will not be civilized, highly cultured, and legal.

In emergency cases, it is necessary to create a law-making working group consisting of the specialists of the relevant state bodies and representatives of civil society. First of all, it should investigate the emerging emergency public relations, predict their changes, develop a strategy, tactics and an operational plan for the purpose of eliminating adverse consequences and stabilizing public relations. A working group should also select appropriate methods and legal and technological means. The question arises how to solve the problem, and what methods and means are better to use to implement it.

The systems engineering approach to law development is to first make a team of experts in all relevant academic subjects. As social problems and their legal solutions, as a rule, have many sociological, economic and legal aspects, the teams of developers should be composed of people who collectively have knowledge and experience in engineering design methodologies and other relevant fields such as sociology, economics, business, political science, law and statistics [36, p. 329].

The methodology of lawmaking technology also makes sense. Without a methodology, no set goals can be achieved. The quality of lawmaking methodology depends on the legal culture of lawmaking and is a mirror image of the level of the right to create. Abstraction and research of the methodology of legal (judicial) technology are very important. It is necessary to devote sections in such disciplines as "Legal Technology"; "Rule-making"; "Power-making"; "Lawmaking" dedicated to the methodology of lawmaking.

Legislative technology investigates and systematizes legal means (legal technique), as well as explores and improves such tools as forecasting, monitoring, strategy (concepts, programs, plans), tactics, principles, methods, techniques and methods and rules of 
legislative technology, without which the implementation of professional work is hard to imagine.

\section{Sentence}

A circumstance that has developed in the legislation of Tajikistan, associated with the registration of a regulatory legal act on amendments to the Constitution of the Republic of Tajikistan, requires operational legislative intervention.

In terms of the theory of law and legal (judicial) technology, legal rules take on a form of a regulatory legal act in Russia and in Tajikistan.

The legislation of Tajikistan does not regulate relations related to changes in the rules of the Constitution of the Republic of Tajikistan, does not provide for the type of document for formalizing amendments to the Constitution of Tajikistan. This circumstance is unacceptable and must be resolved immediately. To fill the current gap, it is necessary to bring into legal circulation a new regulatory legal act on amendments to the Constitution of Tajikistan [37].

One can propose another way to resolve the situation, formalize the content of amendments to the Constitution of Tajikistan in such a type of law as the "Law adopted through a national referendum" regulating important spheres of state and public life, provided for by the legislation of the Republic of Tajikistan, which ranks second in the hierarchy of regulatory legal acts [38, Art. 9.].

\section{References}

1. Tatiana Zamakhina, Rossiyskaya Gazeta, Capital Issue, 69 (8123) April 01 (2020)

2. W.Tim Murphy, International encyclopedia of the social $\&$ behavioral sciences (second edition), 585 (2015)

3. Z.M. Chernilovskii, General history of state and law, 576 (1995)

4. K.M. Umedov, Proceedings of the International scientific-practical conference dedicated to the 20th anniversary of the Constitution of the Republic of Tatarstan: The role of law in modern society: achievements and prospects, Russian - Tajik (Slavic) University - RTSU (Dushanbe, October 17, 2014), 235 (2014)

5. P.A. Guk, Legal technique: "Strategy, tactics, technique of lawmaking", 9, 214 (2015)

6. Jasmin Riedl, Government Information Quarterly, 36(4), 101390, 12 (2019)

7. V.M. Mokienko, T.G. Nikitina, E.K. Nikolaeva, A large dictionary of Russian proverbs, 1024 (2010)

8. V.Ia. Liubiashchits, M.B. Smolenskii, V.I. Shepelev, Theory of state and law, 2, 512 (2003)

9. N.I. Matuzov, A.V. Malko, Theory of state and law: textbook, 4, 528 (2013)

10. A.A. Iugov, Russian law: education practice science, 5, 55 (2018)

11. K.M. Umedov, Proceedings of the XIV International Koniv readings, May 13-14, 2015, Judicial reform of 1864 and its significance for the formation of the legal systems of the states of the post-Soviet space: problems of theory and practice, 188 (2015)

12. Iu.V. Voronin, Lawmaking en masse, May 20, (2015) https://www.garant.ru/

13. E.M. Shulman, Lawmaking as a political process, 184 (2014) 
14. Decree of the Government of the Russian Federation N 715 of December 1, 2004, "On the approval of the list of socially significant diseases and diseases that pose a danger to others", http://docs.cntd.ru/

15. Decree of the Government of the Russian Federation N 66 of December 31, 2020, "On amendments to the list of diseases that pose a danger to others", http://docs.cntd.ru/

16. Federal Law of the Russian Federation N 68-FZ of December 21, 1994 "On the protection of the population and territories from natural and man-made emergencies", http://www.consultant.ru/

17. Federal Law of the Russian Federation No. 27-FZ of 27.02.2007, "On amendments to certain legislative acts of the Russian Federation", http://www.consultant.ru/

18. Federal Law of the Russian Federation No. 98-FZ of 01.04.2020, “On amendments to certain legislative acts of the Russian Federation on the prevention and elimination of emergencies", http://www.consultant.ru/

19. Federal Law of the Russian Federation No. 149-FZ of 24.04.2020, "On amendments to certain legislative acts of the Russian Federation", http://www.consultant.ru/

20. Federal Law of the Russian Federation No. 147-FZ of 24.04.2020, "On amendments to certain legislative acts of the Russian Federation on monitoring the efficiency and quality of exercising powers transferred to state authorities of the subjects of the Russian Federation", http://www.consultant.ru/

21. Federal Law of the Russian Federation No. 124-FZ of 24.04.2020, "On amendments to certain legislative acts of the Russian Federation on ensuring sustainable development of the economy in conditions of a deteriorating situation due to the spread of a new coronavirus infection", http://www.consultant.ru/

22. Federal Law of the Russian Federation No. 153-FZ of 23.05.2020, "On amendments to certain legislative acts of the Russian Federation”, http://www.consultant.ru/

23. Federal Law of the Russian Federation No. 154-FZ of 23.05.2020, "On amendments to certain legislative acts of the Russian Federation”, http://www.consultant.ru/

24. Federal Law of the Russian Federation No. 166-FZ of 08.06.2020, "On amendments to certain legislative acts of the Russian Federation to take urgent measures aimed at ensuring sustainable economic development and preventing the consequences of the spread of a new coronavirus infection", http://www.consultant.ru/

25. Federal Law of the Russian Federation No. 181-FZ of 08.06.2020, "On amendments to certain legislative acts of the Russian Federation in connection with the adoption of the Federal Law "On amendments to the Federal Law "On Individual (personified) accounting in the compulsory pension insurance system" and legislative acts of the Russian Federation", http://www.consultant.ru/

26. Federal Law of the Russian Federation No. 202-FZ of 13.07.2020, "On amendments to the Federal Law "On participation in shared construction of apartment buildings and other real estate objects and on amendments to certain legislative acts of the Russian Federation" and certain legislative acts of the Russian Federation", http://www.consultant.ru/

27. Federal Law of the Russian Federation No. 267-FZ of 31.07.2020, "On amendments to certain legislative acts of the Russian Federation", http://www.consultant.ru/

28. Federal Law No. 127-FZ of 26.10.2002 (as amended on 13.07.2020) "On insolvency (bankruptcy)", http://www.consultant.ru/ 
29. Federal Law of the Russian Federation No. 67-FZ of 12.06 .2002 (as amended on 31.07.2020) "On basic guarantees of electoral rights and the right to participate in a referendum of citizens of the Russian Federation", http://www.consultant.ru/

30. Federal Law of the Russian Federation No. 20-FZ of 22.02.2014 (as amended on 31.07.2020) "On the election of deputies of the State Duma of the Federal Assembly of the Russian Federation", http://www.consultant.ru/

31. Federal Law of the Russian Federation No. 44-FZ of 05.04.2013 "On contract system in the procurement of goods, works and services for state and municipal needs", http://www.consultant.ru/

32. Federal Law of the Russian Federation No. 67-FZ of 26.03.2020, "On amendments to Article 60 of the Federal Law "On circulation of medicines" and Article 38 of the Federal Law "On the fundamentals of health protection of citizens in the Russian Federation", http://www.consultant.ru/

33. Federal Law of the Russian Federation No. 105-FZ of 03.04.2020, "On amendments to Article 15.1 of the Federal Law "On information, information technologies and protection of information" and the Federal Law "On circulation of medicines", http://www.consultant.ru/

34. S.V. Bakhvalov, Legislative technology: some problems of theory and methodology: Cand. Law Thesis, 275 (2006)

35. Reading together, Navigator in the world of books, Posted on 01.10.2015, http://chitaem-vmeste.ru/

36. David G. Schrunk, Conference on Systems Engineering Research (CSER), 8, 327 (2012)

37. K.M. Umedov, Science Magazine, Bulletin Russian Tajik (Slavic) University (RTSU), 3(50), 43 (2015)

38. Law of the Republic of Tajikistan No. 1414 of May 30, 2017, "On regulatory legal acts", http://www.adlia.tj/ 